\title{
KECAKAPAN BERPIKIR DAN PENERAPANNYA DALAM PELAYANAN KRISTEN
}

\section{Sunarto}

\begin{abstract}
ABSTRAK
Berkembangnya kebudayaan di dalam sejarah hidup manusia tidak bisa dilepaskan dari proses berpikir. Tingkat kemajuannya bukan hanya menyentuh masalah ilmu pengetahuan umum, tetapi juga menyentuh ke wilayah pelayanan gerejawi. Apabila kecakapan berpikir juga bersentuhan dengan pelayanan gerejawi, seharusnya kecakapan ini ditumbuhkembangkan oleh setiap orang percaya. Dalam batasan tertentu berpikir dapat diartikan menggunakan akal budi untuk memertimbangkan dan memutuskan sesuatu. Secara teologis manusia diciptakan Allah dengan kemampuan berpikir yang melebihi semua makhluk. Manusia baru di dalam Kristus harus mengarahkan buah pemikirannya untuk hal-hal mulia sama seperti Allah yang memiliki sifat yang mulia. Hasil karya manusia harus digunakan untuk hal-hal yang bermanfaat bagi kehidupan manusia dan sesamanya.
\end{abstract}

\section{PENDAHULUAN}

Salah satu aktivitas di dalam kehidupan manusia adalah berpikir. Berpikir merupakan aktivitas yang membedakan antara manusia dengan makluk lain, misalnya dibandingkan dengan binatang. Berkembangnya kebudayaan di dalam sejarah hidup manusia tidak bisa dilepaskan dari proses berpikir. Buah pikiran yang dikerjakan oleh manusia menghasilkan berbagai kemajuan, mulai teknologi komunikasi, militer, teater, kesehatan, perumahan dan lain-lain. Tingkat kemajuannya bukan hanya menyentuh masalah ilmu pengetahuan umum, tetapi juga menyentuh ke wilayah pelayanan gerejawi. 
Tanpa berpikir manusia tidak bisa menghasilkan berbagai kemajuan yang ada selama ini, termasuk dalam bidang pelayanan Kristen. Kemajuan peradaban yang dihasilkan oleh manusia karena berkaitan dengan kecakapan berpikir itu sendiri. Kecakapan berpikir merupakan bagian ilmu filsafat atau yang lebih dikenal dengan istilah penalaran. "Penalaran merupakan suatu proses berpikir yang membuahkan pengetahuan. Agar pengetahuan yang dihasilkan penalaran itu mempunyai dasar kebenaran maka proses berpikir itu harus dilakukan suatu cara tertentu."1

Apabila kecakapan berpikir juga bersentuhan dengan pelayanan gerejawi, seharusnya kecakapan ini ditumbuhkembangkan oleh setiap orang percaya. Pokok pembicaraan tersebut merupakan salah satu alasan pentingnya memaparkan topik ini. Alasan lain yang mendukung untuk membahas masalah ini, karena manusia diciptakan Allah dengan kemampuan berpikir yang melebihi semua mahluk (Kej. 1:28). Kemampuan berpikir yang dimiliki manusia harus dipersembahkan untuk kemuliaan Allah. Setiap orang yang menerima kasih Allah, Tuhan Yesus mengajarkan kepada murid-muridNya, "Kasihilah Tuhan, Allahmu, dengan segenap hatimu dan segenap jiwamu dan dengan segenap akal budimu: (Mat. 22:37). Hukum kedua yang harus dijalankan adalah "Kasihilah sesamamu manusia seperti dirimu sendiri" (Mat. 22:39).

Bertolak dari dua hukum utama tersebut maka mengasihi Allah dengan segenap hati, jiwa dan akal budi jelas berkaitan dengan kasih sesorang terhadap sesamanya. Apabila aplikasi kasih kepada sesama berkaitan dengan panggilan pelayanan Kristiani, disini ada satu pertanyaan yang patut diajukan! Apakah ada korelasinya antara kecakapan berpikir dengan kemampuan pelayanan seseorang? Andai kata ada korelasi antara kecakapan berpikir dengan kemampuan pelayanan, bagaimanakah aplikasinya dalam pelayanan Kristen? Adakah kendala-

1 Jujun S. Suriasumantri, Filsafat Ilmu Sebuah Pengantar Populer (Jakarta: Pustaka Sinar Harapan, 2009), 46. 
kendala yang turut memengaruhinya. Pertanyaan-pertanyaan inilah yang akan dipaparkan dalam tulisan ini.

\section{DASAR-DASAR ALKITAB TENTANG KECAKAPAN BERPIKIR}

\section{Pengertian Berpikir}

Berpikir adalah bekerja karena itu memerlukan kecakapankecakapan lain disamping kemampuan otak. Berpikir memerlukan ketekunan, pemusatan pikiran, dan suatu cara yang jitu. Seorang pemikir yang pandai dapat menyuruh otaknya menyelesaikan suatu persoalan seperti seorang ahli mesin menjalankan mesin. Ia mengawasi dan mengarahkan pekerjaan mentalnya. ${ }^{2}$

Dalam batasan tertentu berpikir dapat diartikan menggunakan akal budi untuk memertimbangkan dan memutuskan sesuatu; menimbangnimbang dalam ingatan ${ }^{3}$. Dalam arti yang sempit berpikir juga dapat diartikan meletakkan atau mencari hubungan atau pertalian antara abstraksi-abstraksi. Maksudnya abstraksi adalah reaksi atau respons terhadap benda-benda, kejadian-kejadian dan situasi-situasi yang mulamula yang dihadapi sebagai kenyataan ${ }^{4}$.

Kalau berpikir berkaitan dengan reaksi atau respons manusia yang berelasi dengan lingkungannya, dengan demikian berpikir sangat berkaitan dengan tanggapan, ingatan, pengertian dan perasaan. Berkaitan dengan tanggapan berarti berkaitan dengan reaksi dan respons manusia terhadap lingkungannya. Berkaitan dengan ingatan berarti reaksi dan respons seseorang berkaitan dengan pengalaman-pengalaman dimasa lampau. Dilihat dari sisi pengertian berkaitan dengan hasil berpikir dalam

2 Herbert N. Casson, Teknik Berpikir (Tnp Kota: Rabbit Book Indonesia, 1977), 46.

${ }^{3}$ Kamus Besar Bahasa Indonesia (Jakarta: Departemen Pendidikan dan Kebudayaan, 1993), 682.

4 Ngalim Purwanto, Psikologi Pendidikan (Bandung: PT Remaja Rosdakarya, 1994), 43. 
suatu proses. Sedangkan perasaan berarti berkaitan dengan suasana hati seseorang 5 .

Berpikir berkaitan dengan logika, karena logika merupakan ilmu menalar dan seni berpikir dengan tepat dan benar. Dalam logika, seseorang dapat belajar bagaimana mengungkapkan pikiran dengan tepat, jelas, singkat, runtut dan teratur. ${ }^{6}$ Disamping berkaitan dengan logika berpikir juga berkaitan dengan kemampuan inteligensi seseorang. Inteligensi merupakan suatu kemampuan mental yang melibatkan proses berpikir secara rasional. Oleh karena itu inteligensi tidak dapat diamati secara langsung, melainkan harus disimpulkan dari berbagai tindakan nyata yang merupakan manifestasi dari proses berpikir yang rasional. ${ }^{7}$ Jadi supaya manusia bisa berpikir dengan tepat, jelas, runtut dan teratur seseorang harus menggunakan logika dengan baik.

\section{Manusia Diciptakan Allah dengan Kemampuan Berpikir}

Secara teologis manusia diciptakan Allah dengan kemampuan berpikir yang melebihi semua makluk (Kej. 1:28). Perkembangan pemikiran manusia yang terus berkembang karena manusia diciptakan dengan memiliki kedudukan yang mulia bila dibandingkan dengan makluk lainnya. Ketika Allah menciptakan alam semesta dengan seluruh isinya, manusia menempati puncak dari susunan penciptaan. Mandat untuk memelihara, menguasai dan menaklukkan semua ciptaan yang lebih rendah, sesungguhnya merupakan anugerah dari Allah dari sejak semula. Tugas dan tanggung jawab yang diberikan kepada manusia untuk menguasai dan menaklukkan isi alam juga menempatkan manusia

\section{Ibid, 43-44.}

${ }^{6}$ Konrad Kebung, Filsafat Ilmu Pengetahuan (Jakarta: Prestasi Pustaka, 2011), 27.

${ }^{7}$ Irwanto dkk, Psikologi Umum Buku Panduan Mahasiswa (Jakarta: PT Gramedia, 1989), 167. 
sebagai pelayan akan maksud dan kehendak Allah bagi kemuliaan-Nya (Kej. 1:28: Mzm 8:4-9). ${ }^{8}$

Mandat untuk memelihara, menguasai dan menaklukkan isi alam yang dijalankan manusia akan berjalan dengan baik jikalau mau mengembangkan akal budinya. Pengembangan akal budi dapat diartikan bahwa manusia menggunakan pikirannya untuk keperluan kehidupan baik pribadi maupun relasinya dengan sesama. Dari fakta ini dapat dikatakan berpikir tidak bisa terpisah dari kehidupan manusia itu sendiri. Manusia yang tidak beripikir adalah manusia yang sudah mati akal budinya.

Proses berpikir yang dikerjakan oleh manusia menjadi latar belakang munculnya berbagai pengetahuan ilmiah. Berbagai pengetahuan itu melahirkan berbagai teori atau ilmu atau yang lazim disebut sebagai perkembangan ilmu pengetahuan. The Liang Gie "memberikan pengertian ilmu sebagai rangkaian telaahan yang mencari penjelasan suatu metode untuk memeroleh pemahaman secara rasional-empiris mengenai alam-dunia dari pelbagai aspek, dan keseluruhan pengetahuan sistematis yang menjelaskan pelbagai gejala yang mau dimengerti manusia." 9

\section{Buah Pikiran Manusia Harus Dipersembahkan untuk Kemuliaan Allah.}

Manusia yang diciptakan Allah dengan kemampuan berpikir supaya bisa menggunakan kemampuan itu untuk mengerjakan mandat Allah. Mandat itu adalah memelihara, menguasai dan menaklukkan isi alam semesta. Keberdosaan manusia mengalihkan dan melupakan mandat yang diberikan oleh Allah. Manusia menggunakan kemampuan berpikir bukan untuk hal-hal yang baik, hal-hal yang bermanfat bagi sesamanya. Kemampuan berpikir diselewengkan hanya untuk kesombongan

${ }^{8}$ Louis Berkhof, Systematic Theology (Michigan: Eerdmans Publishing CO. Grand Rapids, 1984),183.

${ }^{9}$ Konrad Kebung, Filsafat Ilmu Pengetahuan, 64. 
manusia, menindas dan menguasai sesamanya hanya untuk kepuasan pribadi (Kej. 3:6-7; 5:5; Rm. 1:18-32).

Keberdosaan manusia memberikan inisiatif akan Kasih Allah kepada manusia supaya dapat menggembalikan arah kerja manusia bukan untuk dirinya sendiri, tetapi untuk kemuliaan Allah. Hukum-hukum Allah pun diberikan supaya manusia hidup berkenan pada Allah. Hukum-hukum itu mengatur dalam relasinya manusia dengan Allah, demikian juga manusia dengan sesamanya, termasuk tanggung jawabnya terhadap alam sekitar.

Paulus kepada jemaat di Filipi diingatkan bahwa mereka setelah mengenal Tuhan Yesus Kristus supaya mengarahkan semua buah pemikiran hanya berpusat pada kemuliaan Allah. Filipi 4:8 mendeskripsikan secara jelas demikian: "Jadi akhirnya, saudara-saudara, semua yang benar, semua yang mulia, semua yang adil, semua yang suci, semua yang manis, semua yang sedap didengar, semua yang disebut kebajikan dan patut dipuji, pikirkanlah semuanya itu." Manusia baru di dalam Kristus harus mengarahkan buah pemikirannya untuk hal-hal mulia sama seperti Allah yang memilki sifat yang mulia. Hasil karya manusia harus digunakan untuk hal-hal yang bermanfaat kehidupan manusia dan sesamanya.

\section{Hidup Yesus dan Pemikiran-Nya}

Yesus dalam kemanusiannya yang sempurna selama di dunia juga menggunakan pikirannya bagaimana supaya bisa berkenan kepada Allah Bapa (Filipi 2:5-8). Sejak masa kanak-kanak pemikiran Yesus berkembang secara sempurna seperti seperti yang dicatat oleh Injil Lukas 2:40 "Anak itu bertambah besar dan menjadi kuat, penuh hikmat, dan kasih karunia Allah ada pada-Nya." Ketika Yesus berusia dua belas tahun pikiran-Nya juga digunakan untuk berdialog dengan para alim ulama di Bait Allah (Luk. 2:46-47). Kecerdasan-Nya berkembang secara luar biasa, sehingga bisa bersoal jawab dan jawaban yang diberikan menimbulkan keheranan bagi orang lain. 
Yesus menggunakan pemikirannya secara tepat, kepada yang tepat dan pada waktu yang tepat. Yesus menggunakan pemikirannya untuk mengajar (Mat. 5:2; Mrk. 4:1). Yesus menggunakan pemikirannya untuk membimbing mereka yang tidak mengerti (Luk. 24:17-27). Yesus menggunakannya pemikirannya untuk mengampuni dan menyembuhkan mereka yang sakit (Mat. 9:2-8), untuk menghibur, untuk menasehati maupun untuk menegor mereka yang berdosa (Yoh. 8:2-11).

Ketika Ia berhadapan dengan orang-orang Farisi, Saduki, Ahli-ahli Taurat atau pemimpin Yahudi, Ia selalu berpikir bagaimana mengatasi berbagai cobaan, jalan keluar atau pun mengajarkan kebenaran (Yoh. 8:2-11; Mark. 3:1-6; Luk. 5:17-26). Bahkan dalam posisinya yang sangat sulit karena harus menghadapi salib, Ia mengambil keputusan untuk menaati kehendak Allah Bapa (Mat. 26:3842).

Berbeda dengan Yesus, orang-orang Farisi dan Saduki menggunakan pikiran bagaimana bisa menjebak Yesus sehingga ada alasan untuk menghukumnya. Pikiran mereka bukan bagaimana bisa berkenan pada Bapa, tetapi justru dipakai untuk menjatuhkan Yesus. Sebagai kelompok atau pribadi pemikiran mereka justru diarahkan untuk menjatuhkan Yesus karena dasar pemikirannya diliputi oleh keirian dan kedengkian akan ajaran Yesus.

Yesus selalu menggunakan pikirannya bagaimana supaya bisa berkenan pada Allah, di sisi lain Yudas Iskariot menjadi contoh negatit. Yudas Iskariot menerjemahkan mandat kehidupan hanya untuk ambisi dan kesenangan pribadi. Yudas menjadi model bagaimana seseorang mengembangkan pikiran hanya untuk kepuasan kedagingan dan hawa nasfu duniawi. Orang yang mengembangkan pikiran dengan tidak sejalan dari mandat Allah jelas merupakan satu tindakan yang tidak sesuai maksud Allah sejak semula. 


\section{MENGEMBANGKAN KECAKAPAN BERPIKIR DALAM PELAYANAN KRISTEN}

\section{Ragam Cara Berpikir}

Pada dasarnya teknik berpikir dapat dipelajari oleh seseorang. Meskipun sebagian orang mengalami kesulitan berpikir dengan baik, tetapi sebagian yang lain dapat meningkatkan kemampuan berpikirnya lebih baik dari sebelumnya. Di sini akan dijelaskan beberapa ragam cara berpikir yang dikerjakan oleh manusia. Ragam cara berpikir sesungguhnya merupakan berbagai bentuk pendekatan bagaimana manusia menggunakan pikirannya untuk bekerja dan memecahkan masalah yang dihadapinya.

\section{Berpikir Secara Induktif}

Berpikir secara induktif adalah satu proses berpikir yang bertolak dari khusus menuju kepada umum. Tepat dan tidaknya cara berpikir secara induktif sangat bergantung kepada representatif atau tidaknya sampel yang diambil yang mewakili fenomena secara keseluruhan. Makin besar jumlah sampel yang diambil berarti makin representatif, dan makin menguatkan validitas dari kesimpulan. ${ }^{10}$

Pengetahuan yang didapat melalui pendekatan induktif ternyata juga masih memiliki kelemahan. Sekumpulan fakta belum tentu bersifat konsisten atau bahkan mungkin bersifat kontradiktif. Kesulitan yang lain misalnya, fakta yang tampak belum menjamin tersusunnya pengetahuan yang sistematis. Misalnya dari hasil pengamatan terhadap anak-anak yang memiliki prestasi tinggi di beberapa sekolah menunjukkan bahwa semuanya mempunyai latar belakang orang tua yang mampu secara ekonomi. Seakan-akan ada kaitan antara prestasi tinggi dengan kemampuan ekonomi yang mampu dari orang tua. Pertanyaannya,

10 Jack R. Lumanauw, Diktat Kuliah Metodologi Penelitian (Tanpa Penerbit, 2011), 13-14. 
apakah betul ada hubungan antara kemampuan ekonomi yang mampu dengan hasil prestasi yang tinggi.

\section{Berpikir Secara Deduktif}

Berpikir secara deduktif adalah satu proses berpikir dari hal umum menuju yang khusus. Berpikir secara deduktif, seseorang bertolak dari satu teori atau prinsip atau sebuah kesimpulan yang sudah dianggap benar dan sudah bersifat umum. Dari teori, prinsip atau kesimpulan yang sudah dianggap benar dan berisifat umum, seseorang menampilkan fenomena yang khusus dan mengambil kesimpulan secara kusus dari fenomena tersebut. ${ }^{11}$

Kesimpulan penalaran deduktif menjadi benar jika kedua premis yang digunakan benar dan cara menarik kesimpulannya juga benar. Jika ada yang salah dari ketiga hal di atas, maka kesimpulan yang diambil juga tidak benar. Masalah utama yang menjadi kesulitan dalam pendekatan deduktif adalah: kesulitan untuk menilai kebenaran dari premis-premis yang digunakan. Ini disebabkan karena penalaran yang digunakan bersifat abstrak, lepas dari pengalaman, sehingga tidak mungkin dapat diamati dengan pancaindera.

\section{Berpikir Secara Analogis}

Berpikir secara analogi adalah satu cara berpikir dengan jalan menyamakan atau memerbandingkan fenomena-fenomena yang pernah dialami. Cara berpikir yang demikian seseorang beranggapan bahwa satu kebenaran dari satu fenomena yang pernah dialaminya berlaku pula dengan fenomena yang dihadapi dengan kondisi sekarang. ${ }^{12}$ Dilihat dari kacamata ini berpikir secara analogis juga bisa dimanfaatkan ketika

11 Ibid.

12 Ngalim Purwanto, Psikologi Pendidikan (Bandung: PT Remaja Rosdakarya, 1994), 47-48. 
seseorang mau menjelaskan satu prinsip, ajaran, teori, program, masalah dan lain sebagainya kepada orang lain.

\section{Korelasi berpikir dan Belajar}

Berpikir dan belajar merupakan dua sisi proses yang tidak dapat dipisahkan. Meskipun demikian, keduanya merupakan dua bentuk proses yang berbeda. Belajar adalah suatu proses terjadinya perubahan perilaku, tetapi berpikir tidak selalu menghasilkan perubahan perilaku. Berpikir suatu proses kerja mental yang tidak kasat mata. Proses ini hanya dapat diamati dari perilaku yang Nampak.

Berpikir tidak dapat diamati secara langsung karena merupakan suatu representasi simbolis baik dari suatu obyek, peristiwa, ide, atau hubungan-hubungan antara hal-hal tersebut. Secara singkat, berpikir merupakan suatu proses pengolahan simbolis yang diarahkan pada pengertian yang lebih baik mengenai lingkungan dan dirinya sendiri. Bila pengertian-pengertian yang diperoleh dari proses berpikir dapat mengakibatkan perubahan perilaku yang relatif permanen, maka proses berpikir tersebut menimbulkan proses belajar. ${ }^{13}$

Di atas sudah dijelaskan bahwa berpikir adalah meletakkan atau mencari hubungan atau pertalian antara abtraksi-abstraksi yang melibatkan satu tanggapan, ingatan, pengertian dan perasaan seseorang. Sedangkan belajar dapat diartikan berusaha untuk memeroleh kepandaian atau ilmu. Kalau belajar merupakan usaha untuk memeroleh kepandaian, belajar juga dapat diartikan suatu perubahan dalam tingkah laku, dimana perubahan itu dapat mengarah kepada tingkah laku yang lebih baik baik, tetapi juga bisa mengarah kepada tingkah laku yang lebih buruk.

Dari dua pengertian tersebut maka jelaslah bahwa orang yang sedang belajar pasti melibatkan pikiran. Belajar melibatkan pikiran karena di dalam belajar seseorang berusaha meletakkan dan mencari

${ }^{13}$ Irwanto dkk, Psikologi Umum Buku Panduan Mahasiswa, 106-107. 
hubungan-hubungan di dalam memecahkan satu permasalahan. Seseorang yang belajar tidak mungkin terpisah dari aktivitas pikiran, apabila belajar tanpa melibatkan pikiran namanya bukan belajar. Dilihat dari energi dan waktu yang dibutuhkan antara belajar dan berpikir sangat berkaitan sekali, artinya semakin lama seseorang melakukan aktivitas belajar, maka semakin banyak pula energi dan waktu yang harus dicurahkan untuk berpikir.

\section{Teknik memerkembangkan kecakapan Berpikir}

Secara teknik, kecakapan berpikir perlu didayagunakan dan dikembangkan. Penggembangkan perlu dilakukan melalui satu proses belajar yang dijalankan oleh manusia. Teknik ini dapat diperoleh baik melalui belajar secara formal maupun secara informal. Secara formal seseorang mendapat ilmu dari pendidikan yang sudah dilembagakan secara resmi. Melalui lembaga pendidikan formal seseorang dapat memerkembangkan kecakapan berpikir melalui perkuliahan yang diajarkan oleh seorang dosen. Melalui perkuliahan seseorang dapat mengikuti dengan berbagai program belajar yang sudah ditentukan.

Secara informal seseorang mendapatkan ilmu melalui lingkungan dimana ia bekerja, bergaul dan bermasyarakat. Melalui metode ini teknik kecakapan berpikir juga dapat dikembangkan melalui teori yang dapat diterima baik secara verbal atau buku-buku cetak. Secara verbal seseorang dapat memanfaatkan teman ketika berdiskusi atau forumforum pertemuan yang informal. Kecakapan berpikir juga dapat diperoleh dengan cara membaca buku-buku literatur yang sudah beredar secara luas.

Misalnya, Robert Marzano seperti yang dikutip oleh Joseph Tong ${ }^{14}$ memberikan delapan kategori yang perlu dikembangkan untuk meningkatkan kecakapan berpikir sebagai berikut:

a. Memusatkan pikiran

${ }_{14}$ Robert Marzano, yang dikutif oleh Joseph Tong, Theory Of Thought and Methodology (Mojokerto: Diktat Kuliah S2, 2001), 13-16. 

b. Kecakapan mengggali informasi
c. Kecakapan untuk mengingat
d. Kecakapan untuk mengkoordinasi pemikiran
e. Kecakapan analisis
f. Kecakapan keterampilan
g. Kecakapan integrasi
h. Kecakapan evaluasi

\section{Kecakapan Berpikir dan Buah Pelayanan}

Kecakapan berpikir yang dimiliki oleh manusia pada dasarnya harus digunakan dengan sebaik-baiknya. Hasil kecakapan berpikir tidak dapat dipisahkan dari etika dan moral. "Hasil-hasil kegiatan keilmuan memberikan alternatif untuk membuat keputusan politik dengan berklibat pada pertimbangan moral."15

Penggunaan dengan sebaik-baiknya artinya seseorang harus mencurahkan dengan seluruh dedikasinya sehingga kecakapan berpikir akan bermanfaat bagi sendiri dan sesamanya. Bermanfaat bagi keluarga, masyarakat, gereja dan negara. Dari aspek ini seseorang tidak boleh menyia-yiakan setiap peluang yang baik untuk mengaplikasikan setiap potensi ilmu dengan mencurahkan waktu dan tenaga bagi peningkatan produktivitas kerja.

Sekarang apa hubungannya antara kecakapan berpikir dengan buah pelayanan? Pada bagian di atas sudah diterangkan bahwa kecakapan berpikir diperlukan untuk semua jenis pekerjaan, baik lembaga gerejawi, masyarakat maupun pemerintahan. Semua jenis pekerjaan pasti menginginkan satu hasil yang memuaskan, baik secara kuantitas maupun kualitas.

Hasil pekerjaan seseorang juga diharapkan di lembaga gerejawi, namun hasil pekerjaan di lembaga gerejawi lebih akrab disebut sebagai buah pelayanan. Yesus juga mengajarkan agar murid-murid-Nya sebagai

${ }^{15}$ H.A. Fuad Ihsan, Filsafat Ilmu (Jakarta: Rineka Cipta, 2010), 276. 
orang percaya hidupnya menghasilkan buah (Yoh. 15:8). Yohanes Pembaptis menyerukan kepada semua orang yang sudah bertobat hendaknya hidupnya menghasilkan buah sesuai dengan buah-bauh pertobatan. Paulus juga mengajarkan bahwa orang percaya hendaknya hidupnya juga menghasilkan kehidupan yang sesuai dengan buah Roh Kudus.

Secara kualitas, jati diri kehidupan Kristen hendaknya menghasilkan buah yang sesuai dengan pimpinan Roh Kudus. "Tetapi buah Roh ialah: kasih, sukacita, damai sejaktera, kesabaran, kemurahan, kebaikan, kesetiaan, kelemahlembutan, penguasaan diri” (Galatia 5:22). Sedangkan secara kuantitas kehidupan Kristen mengharapkan satu hasil yang kelihatan secara kasat mata. Misalnya, seorang pedagang pasti mengharapkan supaya usahanya mendapatkan laba. Untuk lembaga gerejawi misalnya seorang gembala sidang pasti mengharapkan penambahan jumlah jemaat yang dilayani.

Meskipun buah pelayanan merupakan harapan bagi semua orang, tetapi faktanya buah pelayanan menghasilkan buah yang berbeda-beda. Mengapa ini bisa terjadi? Karena masing-masing orang memiliki talenta dan karunia yang berbeda pula (Mat. 25:14-30; I Kor. 12, 14;1-25). Permasalahan menjadi berbeda apabila seseorang tidak memanfaatkan semua potensi yang dimiliki sehingga waktunya hanya terbuang untuk keperluan hal-hal yang tidak beguna. Kondisi yang demikian jelas menunjukkan seseorang kurang memanfaatkan semua potensi yang dimilikinya.

Lain halnya jika seseorang sudah berusaha dengan sebaik-baiknya dengan seluruh dedikasinya yang melibatkan semua waktu dan tenaganya, ternyata hasilnya tidak seperti yang diharapkan. Jika seseorang menghadapi fakta yang demikian disinilah letak keterbatasan manusia dan kedaulatan Allah atas hidup manusia. Kewajiban dari manusia menggunakan semua potensi yang telah diterima dari Allah, sedangkan hasilnya Allah yang akan menentukan menurut kedaulatanNya. 


\section{Pendukung, Kendala, Kecakapan Berpikir dan Pelayanan}

Antara kecakapan berpikir dan buah pelayanan memang berkaitan. Pada satu sisi manusia harus menggunakan semua potensi itu dengan sebaik-baiknya. Pada sisi ini manusia harus menghargai semua potensi yang dimiliki dengan menjalankan seluruh dedikasinya. Kemampuan setiap orang berbeda-beda, ada yang diberikan satu, dua atau lima talenta. Tugas manusia adalah menjalankan talenta atau kemampuan itu dengan sebaik-baiknya. Pada sisi lain ada tangan Tuhan yang turut bekerja atas kedaulatan hidup manusia. Dalam kedaulatan-Nya Allah punya maksud dan rencana bagi tiap-tiap orang.

Secara kasat mata buah pelayanan menjadi berbeda karena manusia harus menghadapi berbagai tantangan, baik dari dalam dan luar diri manusia. Tantangan dari dalam bisa menjadi kendala sehingga seseorang tidak bisa mencurahkan semua potensinya dengan baik. Misalnya, seseorang yang terganggu kesehatannya jelas tidak bisa mencurahkan tenaga dan pikirannya dalam melaksanakan tugas dan tanggung jawabnya. Orang yang demikian jelas tidak bisa bekerja dengan seluruh potensinya karena ada hambatan secara fisik. Hambatan secara fisik dapat digolongkan sebagai faktor internal (hambatan dari dalam) karena kendala ini bukan berasal dari fihak lain.

Tantangan dari luar juga turut memberi peran terhadap apa yang dilakukan oleh manusia. Tantangan dari luar disebut juga sebagai faktor eksternal karena datang dari pihak lain yang turut memberi pengaruh dalam memerkembangkan kecapan berpikir. Seseorang walaupun memiliki potensi yang baik, karena tidak ada kesempatan untuk belajar, karena tidak ada biaya juga turut memengaruhi hasil kerja seseorang. Kondisi alam juga turut berpengaruh misalnya bencana alam pasti membutuhkan waktu dan tenaga yang lebih banyak bagi sebuah pekerjaan. 


\section{KESIMPULAN}

Dari semua yang sudah dipaparkan di atas penulis dapat mengambil kesimpulan bahwa kecakapan berpikir dan aplikasinya dalam pelayanan saling berkaitan satu dengan yang lain. Kecakapan berpikir diperlukan untuk semua bidang pelayanan baik lembaga gerejawi maupun pelayanan yang lain. Melalui kecakapan berpikir, manusia bisa membuat program dan mengaplikasikan dalam setiap pekerjaan supaya dapat berkembang dan menghasilkan buah pelayanan. Sedangkan dari sisi buah pelayanan, manusia harus tetap tunduk atas kedaulatan Allah bagi hidup manusia.

Seberapa banyak yang dihasilkan oleh pemikiran manusia, kewajiban manusia adalah mengembangkan semua potensi yang diterima dari Allah dari sejak semula. Mengembangkan etos kerja yang maksimal terhadap semua potensi diri sebagai respons terhadap kasih karunia Allah. Manusia baru di dalam Kristus harus mengarahkan buah pemikirannya untuk hal-hal mulia sama seperti Allah yang memiliki sifat yang mulia. Pada akhirnya buah pikiran manusia harus diipersembahkan untuk kepentingan manusia dan sesamanya bagi kemuliaan Allah.

SUNARTO, menyelesaikan program Sarjana Muda Teologi di Sekolah Tinggi Teologi Injili Efrata (STTI Efrata) Sidoarjo, Sarjana Teologi dan Master of Art di Sekolah Tinggi Teologi Injili Abdi Allah (STT IAA) di Pacet Mojokerto. Magister Teologi diperoleh dari Sekolah Tinggi Baptis Indonesia (STBI) di Semarang. Sekarang melayani sebagai dosen dan Ketua Program Studi di STT SAPPI Ciranjang Cianjur. 